\title{
The impact of COVID-19 on trauma referrals to a National Neurosurgical Centre
}

\author{
Jack Horan ${ }^{1}$ (1) • John C. Duddy ${ }^{1} \cdot$ Brian Gilmartin ${ }^{1} \cdot$ Michael Amoo ${ }^{1} \cdot$ Deirdre Nolan ${ }^{1} \cdot$ Paula Corr $^{1}$. \\ Mohammed Ben Husien ${ }^{1} \cdot$ Ciaran Bolger $^{1}$
}

Received: 23 November 2020 / Accepted: 2 January 2021 / Published online: 7 January 2021

(C) Royal Academy of Medicine in Ireland 2021

\begin{abstract}
Background To investigate the impact of COVID-19 on trauma referrals to a National Neurosurgical Centre during the first wave of COVID-19 in Ireland.

Methods Retrospective analysis of a prospectively maintained database of all trauma referrals to the National Neurosurgical Centre at Beaumont Hospital, Dublin, during the period March 1-May 31, 2019 and 2020. Patient characteristics including age, sex, alcohol use, anticoagulant/antiplatelet use and initial Glasgow Coma Scale (GCS) were recorded. Patients were grouped based on trauma aetiology and diagnosis.

Results There were 527 and 437 trauma referrals in 2019 and 2020 respectively. Overall, there was a $17.1 \%$ reduction in trauma referrals between 2019 and 2020. Traumatic brain injury, spinal injury and cranial fractures referrals reduced $25 \%$ (375 vs 283 ), $59 \%$ (32 vs 13) and 18\% (39 vs 32) respectively from 2019 to 2020. Low-energy falls below $2 \mathrm{~m}$ was the most common mechanism of injury and accounted for 60 and $61 \%$ of referrals in 2019 and 2020. No reduction in road traffic collision (33 vs 34) and assault (40 vs 40 ) referrals were observed between years.

Conclusions COVID-19 has had a significant impact on both the volume and mechanism of trauma referrals to the National Neurosurgical Centre in Ireland, with falls below $2 \mathrm{~m}$ the most common mechanism of trauma referral across both years. The workload remains substantial and a fully resourced neurosurgical department is essential in any future COVID-19 waves.
\end{abstract}

Keywords COVID-19 · Spinal injury · Subdural · Trauma · Traumatic brain injury

Jack Horan

jackhoran27@gmail.com

John C. Duddy

johnduddy@gmail.com

Brian Gilmartin

briangilmartin@rcsi.ie

Michael Amoo

michaelamoo@rcsi.ie

Deirdre Nolan

deirdrenolan@beaumont.ie

Paula Corr

paulacorr@beaumont.ie

Mohammed Ben Husien

mohammedbhusien@rcsi.ie

Ciaran Bolger

cbolger@rcsi.ie

1 Department of Neurosurgery, Beaumont Hospital, Dublin 9, Ireland
COVID-19 is an infectious disease caused by a novel coronavirus which originated in Wuhan, China, in December 2019 [1]. According to the latest data from Johns Hopkins, there are $58,437,864$ cases of COVID-19 with 1,384,897 deaths worldwide [2]. The first reported case in Ireland was on the 29th of February 2020 [3]. Since then, there have been 70,461 cases and 2023 deaths (up to 22 November 2020) [4].

COVID-19 has had a transformative impact on society and healthcare provision globally. Since the emergence of COVID-19, different governments have employed varying measures of lockdown and contact tracing measures to try and contain the spread of the virus. Ireland entered lockdown with the first restrictive measures put into place on the 12th of March 2020. All schools, creches, childcare facilities and nonessential offices were closed, large gatherings cancelled, while social distancing to a distance of $2 \mathrm{~m}$ is now the norm. In addition, visiting restrictions to hospitals were imposed [5]. Throughout the remainder of March, further lockdown measures were introduced. Businesses such as restaurants, pubs 
and non-essential shops were closed, while sporting events were cancelled. The St. Patrick's Day parade and festival was cancelled and on the 24th of March, a full lockdown was imposed. This banned social gatherings of more than 4 people unless from the same household, all non-essential travel to cease, all non-essential retailers to close and for the first time in the state, private hospitals to operate as public hospitals. Citizens were limited to travel $2 \mathrm{~km}(\mathrm{~km})$ in radius from their accommodation for exercise [6]. Phase 1 of reopening Ireland commenced on 18 May 2020. Small gatherings of up to 4 people outdoors with $2 \mathrm{~m}$ distancing up to $5 \mathrm{~km}$ from homes, face masks recommended in public places, construction workers and other outdoor workers can return to work if safe to do so, garden centres reopening while schools, pubs and restaurants were the main changes in phase 1 [7]. A roadmap of further phases and lifting of restrictions in the coming weeks and months outlined with phase 2 commencing on the 8th of June. Restrictions lifted here included being permitted to travel up to $20 \mathrm{~km}$ from home, gatherings of up to 6 people outside the same households allowed indoors and the reopening of non-essential retailers [8]. Trauma by its very nature is unpredictable and occurs in an accidental or emergency setting. A tertiary spinal unit in the UK and regional centre in Germany reported a reduction of $46 \%$ in referrals from February to April when compared to a year previous [9, 10]. The majority of spinal trauma in Ireland is referred to a separate spinal trauma unit, with the National Neurosurgical Centre receiving referrals from our own emergency department or in patients with co-existent spinal and cranial trauma. Outside of spinal surgery, trauma volume and pattern of injury have changed when comparing the COVID-19 period to a period last year in Ireland, Europe and as far as New Zealand [11-15]. Up to now, the effect of COVID-19 itself and the restrictions imposed by the Irish government on the number and pattern of trauma referrals have been unclear.

We report the results of our study comparing trauma referrals to the National Neurosurgical Centre over a 3-month period (1 March to 31 May) in Ireland to the same 3-month period in 2019. We looked at the pattern of trauma and the resulting diagnoses and compared them between years to see what impact COVID-19 had on trauma referrals to the National Neurosurgical Centre.

\section{Methods}

We performed a retrospective analysis of a prospectively maintained database of all trauma referrals to the National Neurosurgical Centre at Beaumont Hospital, Dublin, during the period March 1-May 31. This period was chosen to capture data from the pre-lockdown period, through the period of major restrictions, to the gradual reopening of society. This was compared to the same period from 2019. Beaumont
Hospital is the National Neurosurgical Centre and thus serves close to 4.8 million people, the population of the Republic of Ireland [16].

Patient characteristics including age, sex, alcohol use, anticoagulant/antiplatelet use and initial Glasgow Coma Scale (GCS) were recorded. The trauma aetiology was included and classified as fall, high fall (fall from above $2 \mathrm{~m}$ and above), road traffic collision (RTC), bicycle injury, alleged assault, sports-related head injury, other/miscellaneous and unknown. Sports-related head injuries included rugby, soccer, horse-riding and skateboarding. Bicycle collisions were excluded as they are their own category. Other/miscellaneous injury included injuries on a farm, scaffolding, items falling onto head and other unfortunate accidents where items made contact with the head. Patients under the age of 16 were excluded as the paediatric ward was closed for part of the 2020 time period.

Patients were also grouped by their diagnosis following trauma and these included traumatic brain injury (TBI), cranial fractures, spinal trauma and incidental findings on imaging and normal imaging. TBI encompasses traumatic subarachnoid haemorrhage, acute and chronic subdural haematoma, extradural haematoma, contusions, intraventricular haemorrhage (defined as only blood on scan in ventricles) and nonspecified TBI. In all cases of non-specified TBI, referral books and national imaging systems were searched to identify the specific TBI diagnosis. However, in a very small number of cases, we were unable to identify the specific diagnosis.

\section{Results}

There were 527 (336 male, 191 female) trauma referrals in 2019 and 437 (268 male, 169 female) referrals in 2020. The average number of trauma referrals per day was 5.7 in 2019 and 4.8 in 2020. Trauma referrals for March, April and May were 180, 169 and 178 in 2019 and 127, 144 and 166 in 2020 (Fig. 1). Overall, there was a $17.1 \%$ reduction in trauma referrals between 2019 and the COVID-19 period of 2020. The overall total referrals for 2019 and 2020 by month is shown (Table 1, Fig. 1).

The number of trauma referrals by day is shown for both years. The date of lockdown, 12 March 2020 (red line) and 18 May 2020, phase 1 of reopening (green line) are included (Fig. 2) to show the initial lockdown period.

\section{Overall}

\section{9}

Five hundred twenty-seven patients were referred with trauma in 2019. 63.8\% ( $n=336)$ were male and $36.2 \%(n=191)$ were 
Table 1 Demographics by trauma diagnoses

\begin{tabular}{|c|c|c|c|c|c|c|c|c|c|c|}
\hline Diagnosis & Year & Total & Gender & $\begin{array}{l}\text { Average age } \\
\text { (years) }\end{array}$ & Age 16-64 & Age $65+$ & $\begin{array}{l}\text { GCS } \\
\text { (initial) }\end{array}$ & $\begin{array}{l}\text { Anticoag } \\
\text { Antiplt }\end{array}$ & Alcohol & $\begin{array}{l}\text { Average referral } \\
\text { (day) }\end{array}$ \\
\hline \multirow[t]{2}{*}{ TBI } & 2019 & 375 & $\begin{array}{l}\text { M } 64.8 \% \\
\text { F 35.2\% }\end{array}$ & 65.2 & $\begin{array}{l}48.5 \% \\
(n=182)\end{array}$ & $\begin{array}{l}51.5 \% \\
(n=193)\end{array}$ & 13.4 & $\begin{array}{l}22.1 \% \\
(n=83)\end{array}$ & $\begin{array}{l}14.7 \% \\
(n=55)\end{array}$ & 4.1 \\
\hline & 2020 & 283 & $\begin{array}{l}\text { M } 60.8 \% \\
\text { F } 39.2 \%\end{array}$ & 64.2 & $\begin{array}{l}40.2 \% \\
(n=103)\end{array}$ & $\begin{array}{l}59.8 \% \\
(n=153)\end{array}$ & 13.2 & $\begin{array}{l}29.0 \% \\
(n=82)\end{array}$ & $\begin{array}{l}11.0 \% \\
(n=31)\end{array}$ & 3.1 \\
\hline$\%$ change & & $-24.5 \%$ & & & & & & & & \\
\hline \multirow[t]{2}{*}{ T-SAH } & 2019 & 82 & $\begin{array}{l}\text { M } 67.1 \% \\
\text { F } 32.9 \%\end{array}$ & 62.9 & $44.7 \%(n=34)$ & $55.3 \%(n=42)$ & 12.9 & $\begin{array}{l}18.3 \% \\
(n=15)\end{array}$ & $\begin{array}{l}22.0 \% \\
(n=18)\end{array}$ & 0.90 \\
\hline & 2020 & 46 & $\begin{array}{l}\text { M 50.0\% } \\
\text { F } 50.0 \%\end{array}$ & 60.7 & $\begin{array}{l}46.7 \% \\
(n=21)\end{array}$ & $\begin{array}{c}53.3 \% \\
(n=24)\end{array}$ & 12.8 & $\begin{array}{l}37.0 \% \\
(n=17)\end{array}$ & $\begin{array}{l}15.2 \% \\
(n=7)\end{array}$ & 0.50 \\
\hline$\%$ change & & $-43.9 \%$ & & & & & & & & \\
\hline \multirow[t]{2}{*}{$\mathrm{ASDH}$} & 2019 & 130 & $\begin{array}{l}\text { M } 60.0 \% \\
\text { F } 40.0 \%\end{array}$ & 74.7 & $\begin{array}{l}22.0 \% \\
(n=24)\end{array}$ & $\begin{array}{l}78.0 \% \\
(n=85)\end{array}$ & 13.4 & $\begin{array}{l}30.8 \% \\
(n=40)\end{array}$ & $\begin{array}{l}7.7 \% \\
(n=10)\end{array}$ & 1.40 \\
\hline & 2020 & 116 & $\begin{array}{l}\text { M 62.9\% } \\
\text { F 37.1\% }\end{array}$ & 68.3 & $\begin{array}{l}33.3 \% \\
(n=33)\end{array}$ & $\begin{array}{c}66.7 \% \\
(n=66)\end{array}$ & 12.9 & $\begin{array}{l}36.2 \% \\
(n=42)\end{array}$ & $\begin{array}{l}10.3 \% \\
(n=12)\end{array}$ & 1.26 \\
\hline$\%$ change & & $-10.8 \%$ & & & & & & & & \\
\hline \multirow[t]{2}{*}{$\mathrm{CSDH}$} & 2019 & 33 & $\begin{array}{l}\text { M } 66.7 \% \\
\text { F } 33.3 \%\end{array}$ & 73.0 & $\begin{array}{l}29.2 \% \\
(n=7)\end{array}$ & $\begin{array}{r}70.8 \% \\
(\mathrm{n}=17)\end{array}$ & 13.6 & $\begin{array}{l}12.1 \% \\
(n=4)\end{array}$ & $\begin{array}{l}12.1 \% \\
(n=4)\end{array}$ & 0.36 \\
\hline & 2020 & 19 & $\begin{array}{l}\text { M 57.9\% } \\
\text { F } 42.1 \%\end{array}$ & 73.8 & $\begin{array}{l}23.5 \% \\
(n=4)\end{array}$ & $\begin{array}{c}76.5 \% \\
(n=13)\end{array}$ & 14.8 & $\begin{array}{l}36.8 \% \\
(n=7)\end{array}$ & $0 \%$ & 0.21 \\
\hline$\%$ change & & $-42.4 \%$ & & & & & & & & \\
\hline \multirow[t]{2}{*}{ EDH } & 2019 & 16 & $\begin{array}{l}\text { M } 87.5 \% \\
\text { F } 12.5 \%\end{array}$ & 40.1 & $\begin{array}{l}84.6 \% \\
(n=11)\end{array}$ & $\begin{array}{c}15.4 \% \\
(n=2)\end{array}$ & 12.2 & $0 \%$ & $\begin{array}{l}18.8 \% \\
(n=3)\end{array}$ & 0.17 \\
\hline & 2020 & 20 & $\begin{array}{l}\text { M } 80.0 \% \\
\text { F } 20.0 \%\end{array}$ & 45.4 & $\begin{array}{l}83.3 \% \\
(n=15)\end{array}$ & $\begin{array}{l}16.7 \% \\
(n=3)\end{array}$ & 13.2 & $\begin{array}{l}5.0 \% \\
(n=1)\end{array}$ & $\begin{array}{l}15.0 \% \\
(n=3)\end{array}$ & 0.22 \\
\hline$\%$ change & & $+20.0 \%$ & & & & & & & & \\
\hline \multirow[t]{2}{*}{ Contusion } & 2019 & 99 & $\begin{array}{l}\text { M 60.6\% } \\
\text { F 39.4\% }\end{array}$ & 57.1 & $\begin{array}{l}59.3 \% \\
(n=54)\end{array}$ & $\begin{array}{l}40.7 \% \\
(n=37)\end{array}$ & 14.1 & $\begin{array}{l}17.2 \% \\
(n=17)\end{array}$ & $\begin{array}{l}18.2 \% \\
(n=18)\end{array}$ & 1.08 \\
\hline & 2020 & 75 & $\begin{array}{l}\text { M } 58.7 \% \\
\text { F } 41.3 \%\end{array}$ & 62.4 & $\begin{array}{l}39.1 \% \\
(n=27)\end{array}$ & $\begin{array}{c}60.9 \% \\
(n=42)\end{array}$ & 13.5 & $\begin{array}{l}16.0 \% \\
(n=12)\end{array}$ & $\begin{array}{l}12.0 \% \\
(n=9)\end{array}$ & 0.82 \\
\hline$\%$ change & & $-24.2 \%$ & & & & & & & & \\
\hline \multirow[t]{2}{*}{$\mathrm{IVH}$} & 2019 & 9 & $\begin{array}{l}\text { M } 88.9 \% \\
\text { F } 11.1 \%\end{array}$ & 77.0 & $0 \%$ & $\begin{array}{c}100 \% \\
(n=8)\end{array}$ & 11.5 & $\begin{array}{l}77.8 \% \\
(n=7)\end{array}$ & $\begin{array}{l}11.1 \% \\
(n=1)\end{array}$ & 0.10 \\
\hline & 2020 & 2 & $\begin{array}{l}\text { M 100\% } \\
\text { F 0\% }\end{array}$ & 68.5 & $\begin{array}{l}50.0 \% \\
(n=1)\end{array}$ & $\begin{array}{l}50.0 \% \\
(n=1)\end{array}$ & 7.5 & $\begin{array}{l}50.0 \% \\
(n=1)\end{array}$ & $0 \%$ & 0.02 \\
\hline$\%$ change & & $-77.8 \%$ & & & & & & & & \\
\hline \multirow[t]{2}{*}{ Non-specified } & 2019 & 6 & $\begin{array}{l}\text { M } 100 \% \\
\text { F } 0 \%\end{array}$ & 49.5 & $\begin{array}{l}50.0 \% \\
(n=2)\end{array}$ & $\begin{array}{l}50.0 \% \\
(n=2)\end{array}$ & 14.8 & $0 \%$ & $\begin{array}{l}16.7 \% \\
(n=1)\end{array}$ & 0.06 \\
\hline & 2020 & 5 & $\begin{array}{l}\text { M } 60.0 \% \\
\text { F } 40.0 \%\end{array}$ & 64.2 & $0 \%$ & $\begin{array}{l}100 \% \\
(n=5)\end{array}$ & 14.7 & $\begin{array}{l}40.0 \% \\
(n=2)\end{array}$ & $0 \%$ & 0.05 \\
\hline$\%$ change & & $-16.7 \%$ & & & & & & & & \\
\hline \multirow[t]{2}{*}{ Cranial fractures } & 2019 & 39 & $\begin{array}{l}\text { M 74.4\% } \\
\text { F } 25.6 \%\end{array}$ & 47.5 & $\begin{array}{l}79.5 \% \\
(n=31)\end{array}$ & $\begin{array}{l}20.5 \% \\
(n=8)\end{array}$ & 14.0 & $\begin{array}{l}5.1 \% \\
(n=2)\end{array}$ & $\begin{array}{l}5.1 \% \\
(n=2)\end{array}$ & 0.42 \\
\hline & 2020 & 32 & $\begin{array}{l}\text { M 56.3\% } \\
\text { F } 43.8 \%\end{array}$ & 55.0 & $\begin{array}{l}58.6 \% \\
(n=17)\end{array}$ & $\begin{array}{c}41.4 \% \\
(n=12)\end{array}$ & 14.4 & $\begin{array}{l}3.1 \% \\
(n=1)\end{array}$ & $\begin{array}{l}6.2 \% \\
(n=2)\end{array}$ & 0.34 \\
\hline$\%$ change & & -17.9 & & & & & & & & \\
\hline \multirow[t]{2}{*}{ Spinal trauma } & 2019 & 32 & $\begin{array}{l}\text { M 56.3\% } \\
\text { F } 43.7 \%\end{array}$ & 65.7 & $\begin{array}{l}25.0 \% \\
(n=8)\end{array}$ & $\begin{array}{c}75.0 \% \\
(n=24)\end{array}$ & 14.0 & $\begin{array}{l}12.5 \% \\
(n=4)\end{array}$ & $\begin{array}{l}9.8 \% \\
(n=3)\end{array}$ & 0.35 \\
\hline & 2020 & 13 & $\begin{array}{l}\text { M } 46.2 \% \\
\text { F } 53.8 \%\end{array}$ & 70.3 & $\begin{array}{l}22.2 \% \\
(n=2)\end{array}$ & $\begin{array}{l}77.8 \% \\
(n=7)\end{array}$ & 14.6 & $\begin{array}{l}15.4 \% \\
(n=2)\end{array}$ & $\begin{array}{l}23.1 \% \\
(n=3)\end{array}$ & 0.14 \\
\hline$\%$ change & & $-59.4 \%$ & & & & & & & & \\
\hline \multirow[t]{2}{*}{ Incidental } & 2019 & 5 & $\begin{array}{l}\text { M } 40.0 \% \\
\text { F } 60.0 \%\end{array}$ & 70.2 & $\begin{array}{l}60.0 \% \\
(n=3)\end{array}$ & $\begin{array}{l}40.0 \% \\
(n=2)\end{array}$ & 15 & $0 \%$ & $\begin{array}{l}20.0 \% \\
(n=1)\end{array}$ & 0.05 \\
\hline & 2020 & 14 & $\begin{array}{l}\text { M } 28.6 \% \\
\text { F } 71.4 \%\end{array}$ & 64.5 & $\begin{array}{l}38.5 \% \\
(n=5)\end{array}$ & $\begin{array}{l}61.5 \% \\
(n=8)\end{array}$ & 14.8 & $\begin{array}{l}21.4 \% \\
(n=3)\end{array}$ & $0 \%$ & 0.15 \\
\hline$\%$ change & & $+64.3 \%$ & & & & & & & & \\
\hline \multirow[t]{2}{*}{ Nil } & 2019 & 76 & $\begin{array}{l}\text { M 56.6\% } \\
\text { F } 43.4 \%\end{array}$ & 51.1 & $\begin{array}{l}67.2 \% \\
(n=45)\end{array}$ & $\begin{array}{c}32.8 \% \\
(n=22)\end{array}$ & 14.5 & $\begin{array}{l}9.2 \% \\
(n=7)\end{array}$ & $\begin{array}{l}6.6 \% \\
(n=5)\end{array}$ & 0.83 \\
\hline & 2020 & 95 & $\begin{array}{l}\text { M } 71.6 \% \\
\text { F } 28.4 \%\end{array}$ & 61.4 & $\begin{array}{l}47.6 \% \\
(n=39)\end{array}$ & $\begin{array}{c}52.4 \% \\
(n=43)\end{array}$ & 14.2 & $\begin{array}{l}15.8 \% \\
(n=15)\end{array}$ & $\begin{array}{l}8.4 \% \\
(n=8)\end{array}$ & 1.03 \\
\hline$\%$ change & & +20.0 & & & & & & & & \\
\hline
\end{tabular}


Fig. 1 Total trauma referrals in March to May 2019 and 2020

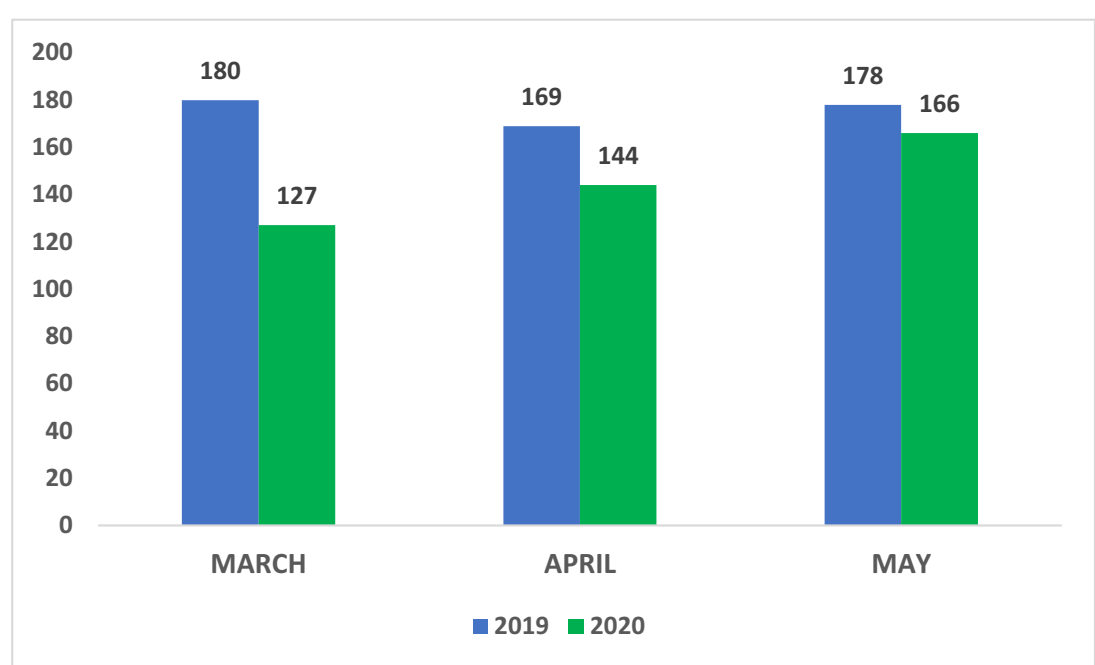

female. The average age of patients referred was 61.9 years, with $54.6 \%(n=288)$ between 10 and 64 and $46.4 \%(n=239)$ 65 and above. The average initial GCS was 13.5 (range 3-15). $7.4 \%(n=39)$ of patients were transferred to the National Neurosurgical Centre. $18.4 \%(n=97)$ were on anticoagulants and in $12.5 \%(n=66)$ alcohol was a factor.
2020

Four hundred thirty-seven patients were referred with trauma in 2020.61.3\% $(n=268)$ were male and $38.7 \%(n=191)$ were female. The average age of patients referred was 63.1 years, with $42.7 \%(n=166)$ between 10 and 64 and $57.3 \%(n=223)$
Fig. 2 Total trauma referrals by day from March 1 to May 31 in 2020 (top) and 2019 (bottom).

Red line denotes the date of first restrictive measures ( 12

March 2020). Green line denotes date of phase 1 of reopening (18 May 2020)

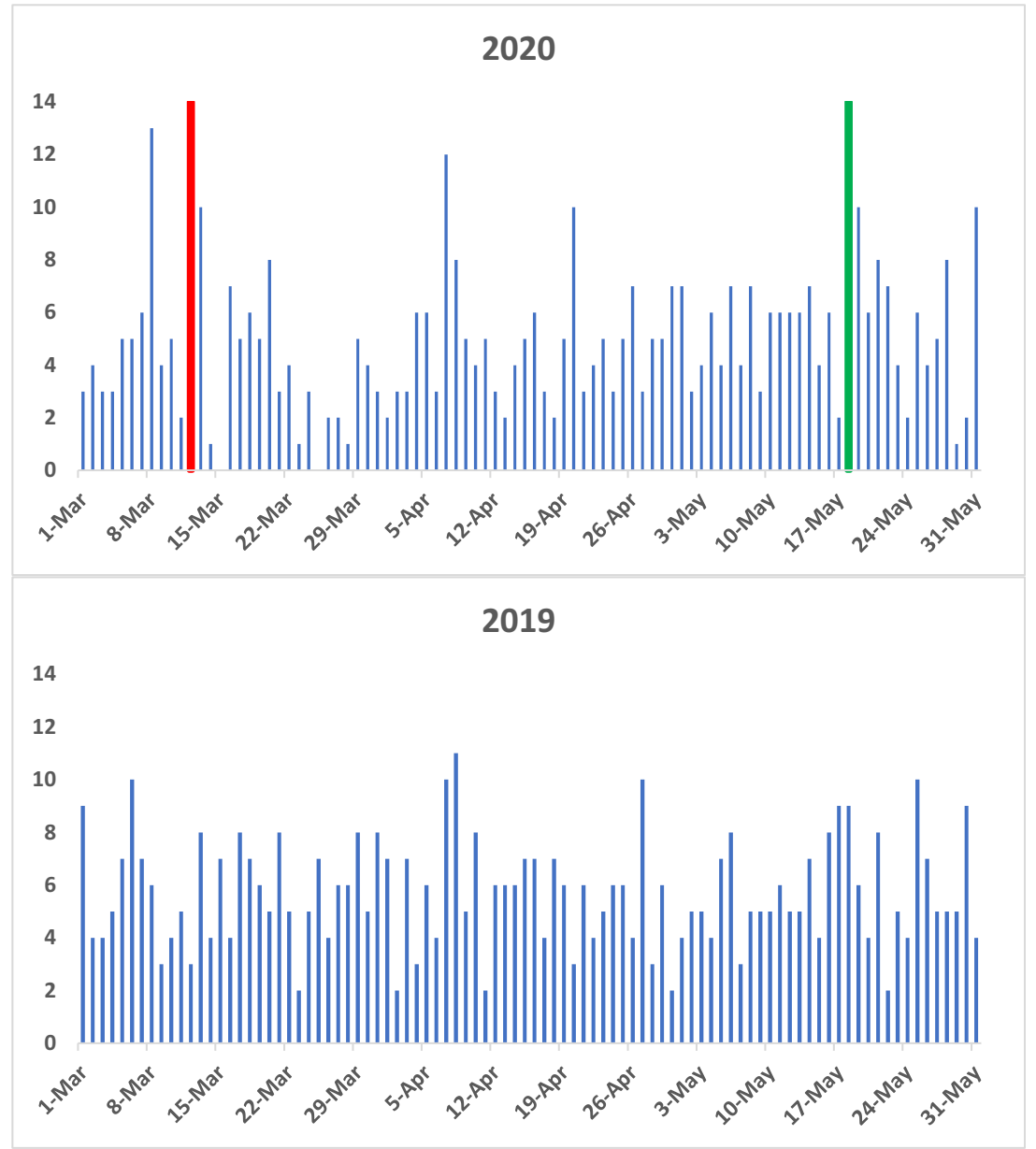


65 and above. The average initial GCS was 13.5 (range 3-15). $7.3 \%(n=32)$ of patients were transferred to the National Neurosurgical Centre. $23.6 \%(n=103)$ were on anticoagulants/antiplatelets and in $10.3 \%(n=45)$ alcohol was a factor.

\section{TBI}

There was a reduction of $24.5 \%$ in TBI referrals between 2019 and 2020 (Table 1). The number of TBI referrals by day is shown for both years. The dates of the first restrictive measures (red line) and phase 1 of reopening (green line) are included (Fig. 3).

\section{Diagnoses}

The breakdown and demographics by diagnoses (traumatic subarachnoid haemorrhage, acute subdural haematoma, chronic subdural haematoma, extradural haematoma, contusion, intraventricular haemorrhage, non-specified, cranial fracture, spinal trauma, incidental findings and nil) are shown in Table 1.

\section{Spinal trauma}

The number of spinal fractures referred from March to May 2019 and 2020 is shown (Fig. 4).

\section{Incidental}

\section{9}

Two meningiomas, 2 space-occupying lesions (SOL) and 1 pituitary SOL were incidental findings. Average incidental referrals per day was 0.05 .
Fig. 3 Traumatic brain injury referrals by day from March 1 to May 31 in 2020 (top) and 2019 (bottom). Red line denotes the date of first restrictive measures (12 March 2020). Green line denotes date of phase 1 of reopening (18 May 2020)

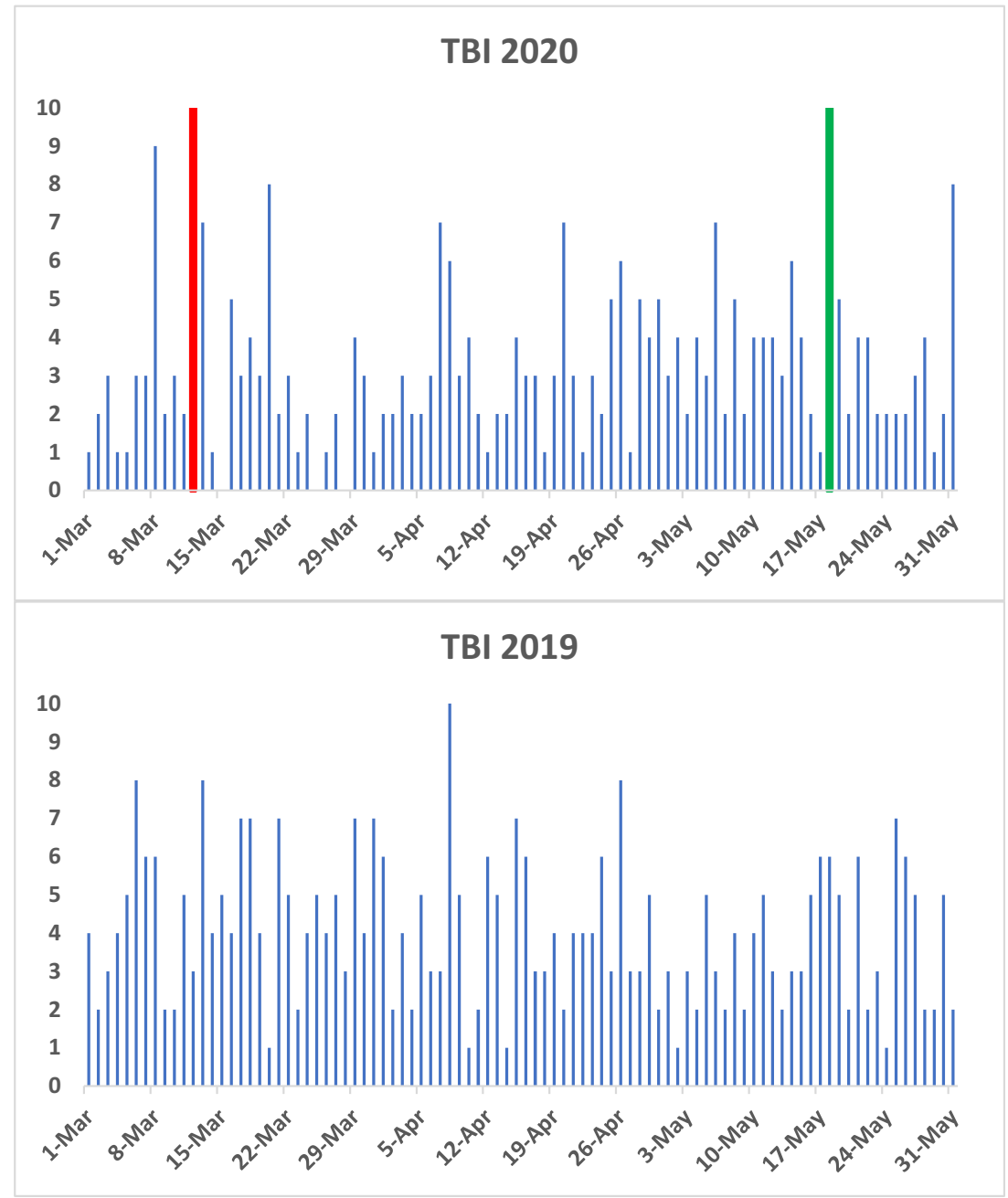


Fig. 4 Spinal trauma referrals in March to May 2019 and 2020

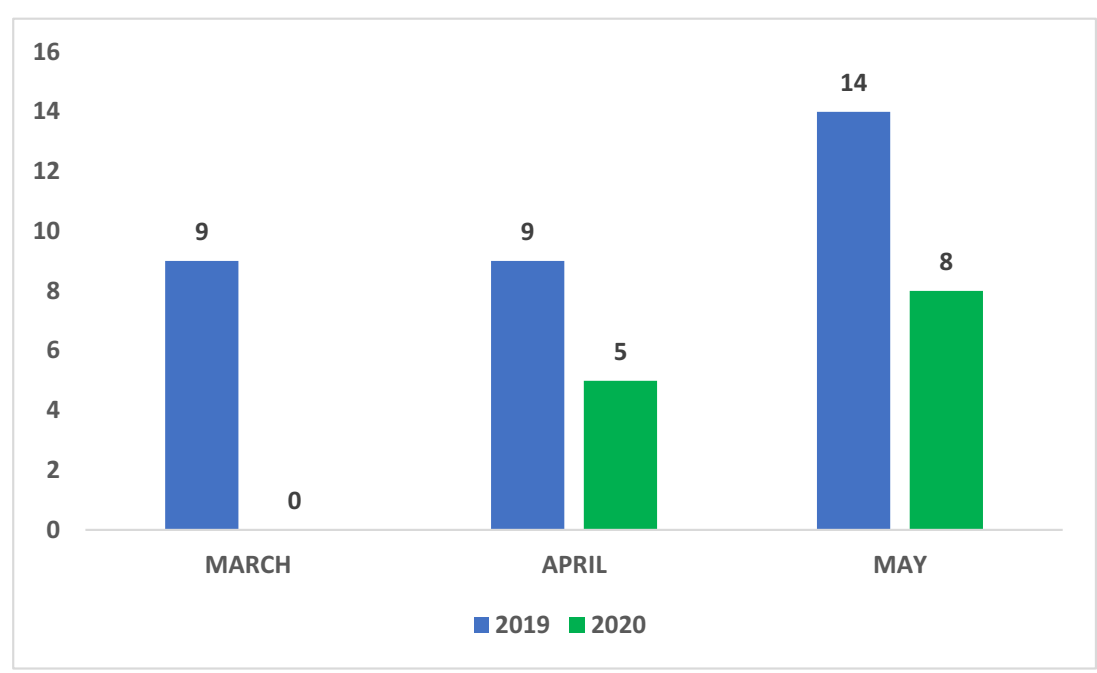

\section{0}

Five aneurysms, 3 meningiomas, 3 vascular abnormalities, 2 pituitary SOLs and $1 \mathrm{SOL}$ were incidental findings. Average incidental referrals per day was 0.15 .

\section{Nil}

\section{9}

$47.4 \%(n=35)$ were referred with a GCS of 15 and a normal scan. Average normal scan referrals per day was 0.83 .

\section{0}

$37.9 \%(n=36)$ were referred with a GCS of 15 and a normal scan. Average normal scan referrals per day was 1.03

\section{Aetiology}

The breakdown and demographics by trauma aetiology (falls, high falls, alleged assault, RTC, bicycle injury, sports-related head injury, other, unknown) are shown in Tables 2 and 3. Trauma aetiology and the resulting diagnoses for 2019 and 2020 are shown (Table 3).

\section{Falls}

Of those aged 65 and above who fell, $61.0 \%(n=117)$ had an initial GCS of 14 or 15 and $59.0 \%(n=69)$ were on anticoagulants/antiplatelets in 2019.
The average number of fall referrals per day in March, April and May 2019 was 3.3, 3.5 and 3.4, with a total average of fall referrals per day 3.4.

Of those aged 65 and above, $61.2 \%(n=109)$ had an initial GCS of 14 or 15 and $43.8 \%(n=78)$ were on anticoagulants/ antiplatelets in 2020 .

The average number of fall referrals per day in March, April and May 2020 was 2.9, 2.9, 3.0, with a total average of fall referrals per day 2.9 .

\section{High falls}

Of those aged 65 and above following high falls, $66.7 \%(n=$ $10)$ had an initial GCS of 14 or 15 and $33.3 \%(n=5)$ were on anticoagulants/antiplatelets in 2019. Average number of high fall referrals per day in March, April and May 2019 was 0.9, 0.6 and 0.4 , with a total average of high fall referrals per day 0.6 .

Of those aged 65 and above, $84.2 \%(n=16)$ had an initial GCS of 14 or 15 and $21.1 \%(n=4)$ were on anticoagulants/ antiplatelets in 2020. Average number of high fall referrals per day in March, April and May 2020 was 0.5, 0.4 and 0.7, with a total average of high fall referrals per day 0.5 .

\section{Road traffic collision}

In $19.5 \%(n=8)$ of RTC referrals, the initial GCS was 8 or less in 2019. This rose to $21.2 \%(n=7)$ in 2020.

\section{Bicycle injury}

In $2019,15.8 \%(n=3)$ of cyclists were wearing helmets at time of injury. In the other $84.2 \%(n=16)$ helmet status was unknown. $36.8 \%(n=7)$ of bicycle injuries in 2019 were cyclists colliding with cars. One case of cyclist colliding with 
Table 2 Demographics by trauma aetiology

\begin{tabular}{|c|c|c|c|c|c|c|c|c|c|c|}
\hline Aetiology & Year & Total & Gender & $\begin{array}{l}\text { Average age } \\
\text { (years) }\end{array}$ & Age 16-64 & Age $65+$ & $\begin{array}{l}\text { GCS } \\
\text { (initial) }\end{array}$ & $\begin{array}{l}\text { Anticoag } \\
\text { Antiplt }\end{array}$ & Alcohol & $\begin{array}{l}\text { Average referral } \\
\text { (day) }\end{array}$ \\
\hline \multirow[t]{2}{*}{ Fall } & 2019 & 314 & $\begin{array}{l}\text { M 56.1\% } \\
\text { F } 43.9 \%\end{array}$ & 70.5 & $\begin{array}{l}56.1 \% \\
(n=176)\end{array}$ & $\begin{array}{l}43.9 \% \\
(n=138)\end{array}$ & 13.8 & $\begin{array}{l}31.2 \% \\
(n=77)\end{array}$ & $\begin{array}{l}18.2 \% \\
(n=45)\end{array}$ & 3.4 \\
\hline & 2020 & 269 & $\begin{array}{l}\text { M 52.8\% } \\
\text { F } 47.2 \%\end{array}$ & 72.1 & $\begin{array}{l}24.9 \% \\
(n=59)\end{array}$ & $\begin{array}{l}75.1 \% \\
(n=178)\end{array}$ & 13.8 & $\begin{array}{l}33.5 \% \\
(n=90)\end{array}$ & $\begin{array}{l}7.8 \% \\
(n=21)\end{array}$ & 2.9 \\
\hline$\%$ change & & $-14.3 \%$ & & & & & & & & \\
\hline \multirow[t]{2}{*}{ High fall } & 2019 & 56 & $\begin{array}{l}\text { M } 75.0 \% \\
\text { F } 25.0 \%\end{array}$ & 53.2 & $\begin{array}{l}70.0 \% \\
(n=35)\end{array}$ & $\begin{array}{l}30.0 \% \\
(n=15)\end{array}$ & 12.1 & $\begin{array}{l}14.3 \% \\
(n=8)\end{array}$ & $\begin{array}{l}19.6 \% \\
(n=11)\end{array}$ & 0.6 \\
\hline & 2020 & 48 & $\begin{array}{l}\text { M } 62.5 \% \\
\text { F } 37.5 \%\end{array}$ & 55.5 & $\begin{array}{l}55.8 \% \\
(n=24)\end{array}$ & $\begin{array}{l}44.2 \% \\
(n=19)\end{array}$ & 12.7 & $\begin{array}{l}12.5 \% \\
(n=6)\end{array}$ & $\begin{array}{l}22.9 \% \\
(n=11)\end{array}$ & 0.5 \\
\hline$\%$ change & & $-14.3 \%$ & & & & & & & & \\
\hline \multirow[t]{2}{*}{ Alleged assault } & 2019 & 40 & $\begin{array}{l}\text { M } 90.0 \% \\
\text { F } 10.0 \%\end{array}$ & 40.7 & $\begin{array}{l}94.4 \% \\
(n=34)\end{array}$ & $\begin{array}{l}5.6 \% \\
(n=2)\end{array}$ & 14.2 & $0 \%$ & $\begin{array}{l}12.5 \% \\
(n=5)\end{array}$ & 0.4 \\
\hline & 2020 & 40 & $\begin{array}{l}\text { M } 90.0 \% \\
\text { F } 10.0 \%\end{array}$ & 40.0 & $\begin{array}{l}90.0 \% \\
(n=33)\end{array}$ & $\begin{array}{l}10.0 \% \\
(n=4)\end{array}$ & 14.3 & $\begin{array}{l}2.5 \% \\
(n=1)\end{array}$ & $\begin{array}{l}12.5 \% \\
(n=5)\end{array}$ & 0.4 \\
\hline$\%$ change & & 0 & & & & & & & & \\
\hline \multirow[t]{2}{*}{$\begin{array}{l}\text { Road traffic } \\
\text { collision }\end{array}$} & 2019 & 33 & $\begin{array}{l}\text { M } 78.8 \% \\
\text { F } 21.2 \%\end{array}$ & 42.3 & $\begin{array}{l}80.0 \% \\
(n=20)\end{array}$ & $\begin{array}{l}20.0 \% \\
(n=5)\end{array}$ & 11.6 & $\begin{array}{l}3.1 \% \\
(n=1)\end{array}$ & $\begin{array}{l}9.1 \% \\
(n=3)\end{array}$ & 0.4 \\
\hline & 2020 & 34 & $\begin{array}{l}\text { M } 67.6 \% \\
\text { F } 32.4 \%\end{array}$ & 43.0 & $\begin{array}{l}81.5 \% \\
(n=22)\end{array}$ & $\begin{array}{l}18.5 \% \\
(n=5)\end{array}$ & 11.7 & $\begin{array}{l}5.9 \% \\
(n=2)\end{array}$ & $\begin{array}{l}5.9 \% \\
(n=2)\end{array}$ & 0.4 \\
\hline$\%$ change & & $+3.1 \%$ & & & & & & & & \\
\hline \multirow[t]{2}{*}{ Bicycle injury } & 2019 & 19 & $\begin{array}{l}\text { M } 89.5 \% \\
\text { F } 10.5 \%\end{array}$ & 42.3 & $\begin{array}{l}82.4 \% \\
(n=14)\end{array}$ & $\begin{array}{l}17.6 \% \\
(n=3)\end{array}$ & 14.0 & $0 \%$ & $\begin{array}{l}15.8 \% \\
(n=3)\end{array}$ & 0.2 \\
\hline & 2020 & 17 & $\begin{array}{l}\text { M 76.5\% } \\
\text { F 23.5\% }\end{array}$ & 39.8 & $\begin{array}{l}94.1 \% \\
(n=16)\end{array}$ & $\begin{array}{l}5.9 \% \\
(n=1)\end{array}$ & 13.9 & $\begin{array}{l}5.9 \% \\
(n=1)\end{array}$ & $\begin{array}{l}17.6 \% \\
(n=3)\end{array}$ & 0.2 \\
\hline$\%$ change & & $-10.5 \%$ & & & & & & & & \\
\hline \multirow[t]{2}{*}{$\begin{array}{l}\text { Sports-related } \\
\text { head injury }\end{array}$} & 2019 & 10 & $\begin{array}{l}\text { M } 70.0 \% \\
\text { F } 30.0 \%\end{array}$ & 23.0 & $\begin{array}{c}100 \% \\
(n=10)\end{array}$ & $0 \%$ & 14.9 & $0 \%$ & $0 \%$ & 0.1 \\
\hline & 2020 & 3 & $\begin{array}{l}\text { M } 66.7 \% \\
\text { F } 33.3 \%\end{array}$ & 59.0 & $\begin{array}{l}33.3 \% \\
(n=1)\end{array}$ & $\begin{array}{l}66.7 \% \\
(n=2)\end{array}$ & 13.5 & $\begin{array}{l}33.1 \% \\
(n=1)\end{array}$ & $0 \%$ & 0.1 \\
\hline$\%$ change & & $-70.0 \%$ & & & & & & & & \\
\hline \multirow[t]{2}{*}{ Other } & 2019 & 14 & $\begin{array}{l}\text { M } 64.3 \% \\
\text { F } 35.7 \%\end{array}$ & 47.8 & $\begin{array}{l}61.5 \% \\
(n=8)\end{array}$ & $\begin{array}{l}38.5 \% \\
(n=5)\end{array}$ & 14.9 & $\begin{array}{l}14.3 \% \\
(n=2)\end{array}$ & $0 \%$ & 0.2 \\
\hline & 2020 & 11 & $\begin{array}{l}\text { M 100\% } \\
\text { F 0\% }\end{array}$ & 54.4 & $\begin{array}{l}63.6 \% \\
(n=7)\end{array}$ & $\begin{array}{l}36.4 \% \\
(n=4)\end{array}$ & 14.4 & $\begin{array}{l}9.1 \% \\
(n=1)\end{array}$ & $\begin{array}{l}9.1 \% \\
(n=1)\end{array}$ & 0.1 \\
\hline$\%$ change & & $-21.4 \%$ & & & & & & & & \\
\hline \multirow[t]{2}{*}{ Unknown aetiology } & 2019 & 41 & $\begin{array}{l}\text { M 56.1\% } \\
\text { F } 43.9 \%\end{array}$ & 64.2 & $\begin{array}{l}37.0 \% \\
(n=10)\end{array}$ & $\begin{array}{l}63.0 \% \\
(n=17)\end{array}$ & 13.9 & $\begin{array}{l}22.0 \% \\
(n=9)\end{array}$ & $\begin{array}{l}2.4 \% \\
(n=1)\end{array}$ & 0.4 \\
\hline & 2020 & 15 & $\begin{array}{l}\text { M 73.3\% } \\
\text { F 26.7\% }\end{array}$ & 68.3 & $\begin{array}{l}23.1 \% \\
(n=3)\end{array}$ & $\begin{array}{l}76.9 \% \\
(n=10)\end{array}$ & 12.0 & $\begin{array}{l}6.7 \% \\
(n=1)\end{array}$ & $\begin{array}{l}13.3 \% \\
(n=2)\end{array}$ & 0.2 \\
\hline$\%$ change & & $-63.4 \%$ & & & & & & & & \\
\hline
\end{tabular}

another cyclist was recorded, with the remaining $57.9 \%(n=$ 11) involving single bicycle collisions.

In 2020, 35.3\% $(n=6)$ were not wearing helmets at time of injury. In the other $64.7 \%,(n=11)$ helmet status was unknown. Only 1 case of bicycle injury in 2020 involved a bicycle and car, the rest were single bicycle injuries involving falls or crashes into stationary objects.

\section{GCS}

The initial GCS was recorded and is shown in Table 4. In 2019 and 2020, the number of patients referred with an initial
GCS of 13 and above was $83.0 \%$ and $79.2 \%$ respectively. Only $9.9 \%$ and $9.7 \%$ of trauma patients had a GCS of 8 and below in 2019 and 2020 .

\section{Discussion}

COVID-19 has had unprecedented effects on our way of life. The restrictive measures implemented in March 2020 by the Irish government to contain the spread of the virus have had a significant impact on both the volume and mechanism of trauma referrals to the National Neurosurgical Centre in Ireland [5]. Overall, there were 964 trauma cases referred over a 3- 
Table 3 Trauma aetiology and diagnosis in 2019 and 2020. (INC is incidental findings)

\begin{tabular}{|c|c|c|c|c|c|c|c|c|c|}
\hline Aetiology & Year & TBI & Spinal & Cranial & $\mathrm{INC}$ & Nil & Total & $\%$ total & $\%$ change \\
\hline \multirow[t]{2}{*}{ Falls } & 2019 & 247 & 12 & 13 & 4 & 38 & 314 & 59.6 & \\
\hline & 2020 & 175 & 8 & 18 & 12 & 56 & 269 & 61.6 & -14.3 \\
\hline \multirow[t]{2}{*}{ High Falls } & 2019 & 37 & 7 & 6 & 0 & 6 & 56 & 10.6 & \\
\hline & 2020 & 35 & 2 & 6 & 0 & 5 & 48 & 11.0 & -14.3 \\
\hline \multirow[t]{2}{*}{ Assault } & 2019 & 23 & 2 & 8 & 1 & 6 & 40 & 7.6 & \\
\hline & 2020 & 21 & 0 & 4 & 0 & 15 & 40 & 9.2 & 0 \\
\hline \multirow[t]{2}{*}{ RTC } & 2019 & 23 & 2 & 1 & 0 & 7 & 33 & 6.3 & \\
\hline & 2020 & 22 & 1 & 3 & 0 & 8 & 34 & 7.8 & +3.1 \\
\hline \multirow[t]{2}{*}{ Bicycle } & 2019 & 9 & 0 & 5 & 0 & 5 & 19 & 3.6 & \\
\hline & 2020 & 10 & 0 & 1 & 0 & 6 & 17 & 3.9 & -10.5 \\
\hline \multirow[t]{2}{*}{ Sporting } & 2019 & 4 & 0 & 2 & 0 & 4 & 10 & 1.9 & \\
\hline & 2020 & 2 & 0 & 0 & 0 & 1 & 3 & 0.7 & -70.0 \\
\hline \multirow[t]{2}{*}{ Other } & 2019 & 8 & 0 & 1 & 0 & 5 & 14 & 2.7 & \\
\hline & 2020 & 7 & 0 & 0 & 1 & 3 & 11 & 2.5 & -21.4 \\
\hline \multirow[t]{2}{*}{ Unknown } & 2019 & 24 & 9 & 3 & 0 & 5 & 41 & 7.8 & \\
\hline & 2020 & 11 & 2 & 0 & 0 & 2 & 15 & 3.4 & -63.4 \\
\hline Total & & & & & & & & & -17.1 \\
\hline
\end{tabular}

month period in 2019 and 2020, with an average age of 62.4 years. A $17.1 \%$ reduction in trauma referrals was seen during the COVID-19 period when compared to the same period 12 months prior. The severity of trauma was similar, with less than $10 \%$ of all patients referred with a GCS of 8 or less (Table 4). Falls under $2 \mathrm{~m}$ in height were by far the most common mechanism of injury and accounted for $59.6 \%$ and $61.6 \%$ of all trauma referrals in 2019 and 2020 respectively (Table 2). Falls under $2 \mathrm{~m}$ accounted for $58 \%$ of trauma referrals in the national Major Trauma Audit (MTA) in 2018 and

Table 4 Initial GCS recorded at referral for 2019 and 2020

\begin{tabular}{|c|c|c|c|c|}
\hline \multirow[b]{2}{*}{ GCS } & \multicolumn{2}{|l|}{2019} & \multicolumn{2}{|l|}{2020} \\
\hline & $\%$ & $\%$ of total & $\%$ & $\%$ of tota \\
\hline 3 & 3.5 & & 4 & \\
\hline 4 & 0.4 & & 0.9 & \\
\hline 5 & 0.7 & & 0.9 & \\
\hline 6 & 1.1 & & 2.7 & \\
\hline 7 & 1.4 & & 0.9 & \\
\hline 8 & 2.8 & 9.9 & 0.4 & 9.7 \\
\hline 9 & 1.8 & & 4.9 & \\
\hline 10 & 1.8 & & 0.4 & \\
\hline 11 & 2.1 & & 1.8 & \\
\hline 12 & 1.4 & 7.1 & 4 & 11.1 \\
\hline 13 & 4.2 & & 2.2 & \\
\hline 14 & 24.4 & & 26.1 & \\
\hline 15 & 54.4 & 83.0 & 50.9 & 79.2 \\
\hline
\end{tabular}

emphasises that the aetiology of trauma has not changed [17]. While a reduction in trauma was observed, there were still 438 trauma referrals over the time period, highlighting the importance of maintaining a fully functional neurosurgical service during the time period and for any future potential COVID-19 waves. Road traffic collisions and alleged assaults remained stable over the COVID period in contrast to all other injury types where a reduction in incidence was observed.

As expected, these changes in the volume of trauma presentation are not unique to Ireland and several neurosurgical and trauma units worldwide have reported their experiences during the COVID-19 period (Table 5). Ahuja et al. [9] reported a $46 \%$ decrease in acute spinal referrals to a tertiary centre in Wales over a 3-month period when compared to last year. Our study reported a decrease of $59 \%$ in spinal trauma over our time period. This decrease is out of proportion to the expected decrease. The most common cause of trauma referral overall and in spinal trauma was falls under $2 \mathrm{~m}$. The proportional decrease in spinal injury is curious. It could be expected that people will continue to have these low-energy falls, regardless of what restrictions are in place. The average age of spinal trauma referred in 2019 was 65.7. With government restrictions advising cocooning for an older population, perhaps this restriction of movement in the elderly population has directly reduced the chances of falling as is explained in more detail below when discussing falls. The numbers involved are low and account for 3-6\% of total trauma referrals to the National Neurosurgical Centre as the majority of spinal injuries are referred to a separate spinal injuries unit. In Germany, a reduction of $46 \%$ was seen in neurosurgical emergency admissions over a 2 and a half month COVID period compared 
Table 5 A comparison of published studies and the impact COVID-19 had on referrals or admissions in a trauma or emergency setting in neurosurgery and other specialities

\begin{tabular}{|c|c|c|c|c|c|c|c|}
\hline Author and year & Country & Speciality & Time period & $\begin{array}{l}\text { Admission/ } \\
\text { referral }\end{array}$ & $\begin{array}{l}2018 / 19 / 20 \\
\text { non-COVID } \\
\text { period }\end{array}$ & $\begin{array}{l}2020 \text { COVID } \\
\text { period }\end{array}$ & $\%$ change \\
\hline \multicolumn{8}{|l|}{ Neurosurgery } \\
\hline Current study & Ireland & NS & March 1-May 31, 2019 and 2020 & Referrals & 437 & 527 & -17 \\
\hline Ahuja 2020 & UK & NS & February 1-April 30, 2019 and 2020 & Referrals & 152 & 82 & -46 \\
\hline Hecht 2020 & Germany & NS & February 1-April 15, 2019 and 2020 & Admission & 655 & 352 & -46 \\
\hline \multicolumn{8}{|c|}{ Trauma and orthopaedics } \\
\hline Fahy 2020 & Ireland & $\begin{array}{l}\text { Emergency } \\
\text { department }\end{array}$ & March 27-April 27, 2019 and 2020 & Referrals & 174 & 136 & -21 \\
\hline Park 2020 & UK & $\mathrm{T} \& \mathrm{O}$ & March 17-April 16, 2019 and 2020 & Referrals & 162 & 87 & -46 \\
\hline Hernigou 2020 & Belgium & $\mathrm{T} \& \mathrm{O}$ & March 1-April 15, 2018 and 2020 & Admission & 132 & 88 & -32 \\
\hline Nuñez 2020 & Spain & $\mathrm{T} \& \mathrm{O}$ & $\begin{array}{l}4 \text { periods: } \\
\text { March 17-April 5, 2018; } \\
\text { March 16-April 4, 2019; } \\
\text { February 23-March 13, 2020; } \\
\text { March 14-April 2, } 2020\end{array}$ & Referrals & $\begin{array}{l}1909 \\
2161 \\
1983 \\
\text { (Average 2018) }\end{array}$ & 512 & -75 \\
\hline Christey 2020 & New Zealand & $\mathrm{T} \& \mathrm{O}$ & $\begin{array}{l}\text { March 5-18, 2020, } \\
\quad \text { March 26-April 8, } 2020\end{array}$ & Admission & 124 & 71 & -43 \\
\hline \multicolumn{8}{|c|}{ Other surgical specialities } \\
\hline Sugrue 2020 & Ireland & Plastic surgery & March 18-April, 2018-2020 & Referrals & $\begin{array}{l}45(18) \\
49(19) \\
\text { (Average 47) }\end{array}$ & 48 & +2 \\
\hline Valand 2020 & UK & Plastic surgery & $\begin{array}{l}\text { January } 2020 \text { (4 weeks), } \\
\text { March } 2020 \text { (4 weeks) }\end{array}$ & Referrals & 213 & 75 & -65 \\
\hline Motterle 2020 & Italy & Urology & $\begin{array}{l}\text { February 24-March 31, 2019, } \\
\text { February 22-March 30, } 2020\end{array}$ & Referrals & 266 & 107 & -60 \\
\hline
\end{tabular}

to 2019 [10]. There were significant reductions in total numbers across all subspecialties including vascular, spinal and hydrocephalus. A very important result from this paper was their observation that patients with spinal injuries presented $48 \mathrm{~h}$ later this year compared to last year, even with similar symptoms. Older patients with chronic subdural haematomas were less likely to present to medical attention. When they did, their symptoms were worse and they had a higher risk of leaving hospital with unfavourable outcomes compared to 12 months before. In our cohort, there was a $42.4 \%$ decrease in chronic subdural haematoma referrals in 2020 when compared to 2019. This reduction likely reflects the overall lower number of falls. A proportion of this may be due to elderly people not presenting to medical attention due to the fear of contracting COVID-19. We did not directly record outcomes in these patients. One surrogate that could be used is the GCS of patients when they were referred with CSDH. The initial GCS in 2019 was 13.6 compared to 14.8 in 2020 . However, this does not tell the full story and future areas of research could investigate outcomes in these patients. This is an important result for public health beyond neurosurgery itself. Delays to presentation or not presenting at all can have detrimental adverse effects in neurosurgical trauma or emergencies that can rapidly progress and leave permanent neurological deficits. These presentation delays are seen worldwide in other emergency and time-critical events across including ischaemic stroke and myocardial infarction [18-21]. This illustrates the delicate balance public health authorities have had to deal with during the COVID-19 pandemic, i.e. trying to suppress the spread of the virus while also advising the public to attend healthcare facilities with non-COVID illness or symptoms.

In our study, a $17 \%$ decrease in trauma referrals was observed in 2020. It is difficult to say if this reduction is solely attributable to the lockdown restrictions and the resulting change in our living patterns. Are patients avoiding presenting to medical attention for fear of becoming infected with COVID-19? A letter to the editor by Tartara et al. [22] with the emotive title 'Are we forgetting non-COVID-19-related diseases during lockdown?' raises this question. The Health Service Executive, Irish Medical Organisation and Irish College of General Practitioners have recognised this issue and have advertised and advised people to present to medical attention if unwell to minimise delayed presentations in conditions like stroke and myocardial infarction as above [23, 24].

Decreases in referrals and emergency presentations are not exclusive to neurosurgery. Various studies in trauma and other 
surgical specialities have reported changes in the volume of emergency presentations (Table 5). Orthopaedic admissions in a Belgian study were reduced 32\% during the COVID-19 period [13]. A study in the UK found a reduction of $46 \%$ in orthopaedic trauma referrals to a level 1 trauma centre over a month [14]. In the first 20 days of Spain's state of emergency, there was a reduction of about $75 \%$ in referrals to a tertiary trauma centre when compared to 3 other 20-day periods that did not include the COVID-19 period. The average age of this cohort was younger than ours at 55.1, compared to ours of 62.4 years [15]. A $43 \%$ decrease in trauma admissions in New Zealand with a decrease of $50 \%$ in males has been reported. The highest reduction in trauma was seen in males and major trauma. The least reduction was seen in females [12]. These are in contrast to our study where there was a $30 \%$ and $20 \%$ reduction in trauma referrals in females and males respectively. Outside of neurosurgery and orthopaedic trauma, studies in plastic surgery trauma and urology emergency volume presentations in Europe have reported their experience COVID-19 has had. In Ireland, in the same hospital as our study, they noted a $2 \%$ increase in hand trauma referrals. Their level of referrals and actual surgeries over a month in 2018 to 2020 was equivalent. They attribute the lack of decline due to increased home DIY and resulting hand injuries [25]. Valand et al. [26] study contrasts this with a reduction of $65 \%$ of hand trauma referrals in a UK district hospital. Outside of hand trauma, there was a reduction of $60 \%$ in emergency department urological emergency referrals [27]. These studies demonstrate that COVID-19 has resulted in a decrease in trauma and emergency presentations of up to $75 \%$ across different specialities globally.

The average age of patients that were referred with trauma to the National Neurosurgical Centre was 62.4 years and $62.7 \%(n=604)$ were male. Patients aged $16-64$ in 2019 made up $54.6 \%$ of the group but in 2020 this age group was reduced to $42.6 \%$. A $17.1 \%$ decrease in traumatic referrals during the COVID period was observed when compared to 2019. This was a similar reduction in trauma referrals when compared to the $21 \%$ reduction in trauma referrals over a month of the COVID period in an Irish emergency department [11]. Low-energy falls below $2 \mathrm{~m}$ was the most common mechanism of trauma in both years and accounted for $59.6 \%$ and $61.6 \%$ of all trauma referrals in 2019 and $2020.78 .6 \%$ in 2019 and $65.1 \%$ in 2020 experienced a traumatic brain injury from a fall. These numbers are similar to the Major Trauma Audit (MTA) 2018 and an Irish study that reported trauma referrals to a model-3 hospital $[11,17]$.

In the MTA report, the average age of major trauma was 59 and $57 \%$ experiencing major trauma were male. Forty-six percent were aged 65 and over. Fifty-eight percent were injured from a low fall and 10\% from a high fall (above $2 \mathrm{~m}$ ). Our results are almost identical to these with $59.6 \%$ and $61.6 \%$ suffering a fall and $10.6 \%$ and $11.6 \%$ experiencing a high fall over both years. Patients with low falls were on average aged 70.5 and 72.1 years in 2019 and 2020 . Patients with falls aged over 65 had a GCS of 14 and above in $61.0 \%$ and $61.2 \%$ of the time. Seventy-two percent of falls resulted in traumatic brain injury averaged over the two time periods. Overall, traumatic brain injury occurred in $71.2 \%$ and $64.8 \%$ in 2019 and 2020 . This is a truly significant number as TBI has significant morbidity and an estimated 30 day mortality of $21 \%$ in International studies [28]. There were 3.4 and 2.9 falls referred per day in 2019 and 2020 respectively. These have important public health and societal implications. Interestingly, Nuñez et al. [15] looked at trauma presentations to a tertiary hospital in Spain during the COVID period and found osteoporotic hip fracture presentations remained stable while most other trauma presentations reduced considerably. Falls are multifactorial and have modifiable and non-modifiable components. Programmes to address these low-energy falls need to identify at-risk individuals and perform an intervention. Interventions proven to significantly reduce falls risks include home exercise and balance programmes and Tai Chi $[29,30]$. Group classes for elderly people are not advisable with social distancing and cocooning advice. One potential solution is to have online classes where elderly people could take part in live online classes with an instructor while they are in their own home. The multifactorial nature of falls highlights the scale and difficulty in targeting this group to prevent TBI.

The severity of trauma presenting to the National Neurosurgical Centre was stable over the 2 years. Overall, less than $10 \%$ of trauma referrals had a severe TBI and a GCS of 8 or less. Eighty-three percent of trauma referrals in 2019 and $79 \%$ cases in 2020 had a GCS of 13 and above. This slight increase in a more severe form of TBI may be accounted for by an increase of 5.5\% high-energy trauma in our study ( $26.4 \%$ versus $31.9 \%$ ). We classed high-energy trauma to include the categories high falls, assault, RTCs and bicycle injuries. Aluha et al. [9] noted a shift in pattern of injury in the opposite direction with less high-energy trauma and more low-energy falls from standing. An interesting subgroup of our study is patients with normal scans that were referred with trauma. $47.5 \%$ in 2019 and $37.9 \%$ in 2020 of patients with normal scans also had a GCS of 15 . This represents $6.7 \%$ and $8.2 \%$ of all trauma referrals in 2019 and 2020 respectively. The reduction in referral of normal scans reflects a reduction in the numbers with minor head injury attending ED during the pandemic.

Two interesting and unexpected results are those regarding the number of road traffic accidents and assaults. These two very questions were raised by Patrick Mitchell's editorial in the British Journal of Neurosurgery, asking would RTCs be down with less traffic on the road and lower number of assaults with less 'alcohol fuelled brawling' [31]. 
There was an increase of $3.1 \%$ in RTC trauma referrals during the COVID-19 period when compared to 2019. This was the only mechanism of injury that increased between years, making the result even more curious. During lockdown, there was a $2-\mathrm{km}$ distance imposed on everyone except if you were going to work in an essential service or needed to travel for food or essential goods. Schools were closed in addition to the majority working from home so car travel was not required for most. Traffic was noticeably lower during lockdown with passing a car on a national road a rare occasion. According to the Irish National Police and Security Service, An Garda Síochána speeding has increased over the past months including the lockdown period across all speeding zones [32]. A similar increase was recorded across London during the lockdown period [14]. While the overall number of cars on the roads were down, those that were may have been travelling faster. If these cars were involved in collisions at higher speeds, the resulting higher energy trauma may be associated with increased head injuries in a lower amount of collisions overall. Gardaí have enacted National Slow Down days with an effort to slow down motorists across the country [32]. Bicycle collisions were down by $10 \%$ from last year. The pattern of bicycle collisions has changed during the COVID period. In 2019, 37\% of bicycle injuries involved a bicycle colliding with a car. This was only $6 \%$ in 2020 . A reason for this could be the reduced traffic on roads. With most working from home, cycling to work rates are likely much reduced. Where cycling injuries did occur this year, they involved the cyclist crashing or falling off following collisions with stationary objects. About $35 \%$ of 2020 cyclists injured were not wearing helmets. This may point to more 'local' cycling if the lockdown travel restrictions were adhered to. Cycling may have been for short distances and periods of time and not on busy main roads where the risk of colliding with cars and danger is increased and more safety precautions are taken.

Trauma referrals due to alleged assaults had no difference in numbers between 2019 and 2020. Forty assaults were recorded in both years, with 2020 having an increased proportion of trauma referrals due to lower overall numbers. We propose that there was a decrease in alcohol-, bar- and public-related assaults in 2020 but an increase in domestic violence. Historically, domestic violence incidences have increased following natural disasters. In a qualitative study in Australia following bushfires, 30 women reported that domestic violence increased, with 17 of the 30 reporting new domestic violence [33]. Unfortunately, during lockdown, many people may not have had anywhere to go and were exposed to domestic violence. Quarantine conditions can exacerbate alcohol abuse and depression and stress in general [34]. Operation Faoiseamh is an operation that was launched on April 1,2020, to contact victims of domestic abuse and assess if they have any acute concerns and give support. This Operation has reported an increase of $25 \%$ in domestic abuse incidents compared to last year [35]. A report by Women's Aid, an Irish organisation working to stop domestic violence against women and children, found an increase of $43 \%$ calls and $71 \%$ in visits to their website from the end of March to the end of June when compared to 2019 [36]. The head of the national policing service reported an increase of $20 \%$ in calls out to domestic violence incidents since the end of March [37]. In the UK, a BBC Panorama investigating domestic violence during the pandemic found that there was a call to police due to domestic violence every $30 \mathrm{~s}$ during the first 7 weeks of lockdown [38]. Unfortunately, the stable rate of alleged assaults may be attributable to increased domestic violence. These are deeply concerning and levels of assault may be increased in prolonged restriction and potential easing and tightening of lockdown restrictions over the next few months.

While a decrease was observed, the volume of trauma cases referred to the National Neurosurgical Centre was still a significant number at 437 over a 3 -month period. This study only reports trauma referrals and does not include the wide range of other neurological emergencies or referrals the centre receives, including neurovascular, hydrocephalus, neuro-oncology, degenerative spine and intracranial infection referrals. In future waves of COVID-19 infections, large numbers of staff may become ill and unable to work. There is a potential that staff and resources may need to be reallocated to areas that require reinforcements. As the National Neurosurgical Centre, it is imperative that the service continues to have adequate staffing and access to theatre to continue the provision of the highest quality neurosurgical care regardless of what future waves of COVID-19 may entail.

Limitations of this study are the retrospective nature of the study. Only referrals relating to trauma were included in this analysis. In a very small number of referrals, relevant information was missing. Future areas of investigation could include the admissions of all neurosurgical pathologies to the National Neurosurgical Centre over the same time period.

\section{Conclusion}

COVID-19 has had a significant impact on both the volume and mechanism of trauma referrals to the National Neurosurgical Centre in Ireland. A 17\% reduction in trauma referrals overall was seen during the COVID period when compared to last year. The most common mechanism of injury leading to referral to the National Neurosurgical Centre was low-energy falls in an older population. Our results mirror the results from the National Trauma Audit of 2018 and highlight the importance of targeting this at-risk group for preventative strategies to reduce morbidity and mortality. Road traffic collisions and alleged assaults were two mechanisms of trauma where numbers did not reduce between years, and targeted initiatives to address these may lead to a reduction in referral 
numbers in subsequent waves of the virus. The workload remains substantial and a fully resourced neurosurgical department is essential in any future COVID-19 waves.

\section{Compliance with ethical standards}

Conflict of interest All authors certify that they have no affiliations with or involvement in any organization or entity with any financial interest (such as honoraria; educational grants; participation in speakers' bureaus; membership, employment, consultancies, stock ownership or other equity interest; and expert testimony or patent-licencing arrangements) or nonfinancial interest (such as personal or professional relationships, affiliations, knowledge or beliefs) in the subject matter or materials discussed in this manuscript.

Ethical approval All procedures performed in studies involving human participants were in accordance with the ethical standards of the institutional and/or national research committee and with the 1964 Helsinki declaration and its later amendments or comparable ethical standards. For this type of study formal consent is not required.

\section{References}

1. Q\&A on coronaviruses (COVID-19). https://www.who.int/ emergencies/diseases/novel-coronavirus-2019/question-andanswers-hub/q-a-detail/q-a-coronaviruses

2. Johns Hopkins University. https://coronavirus.jhu.edu/map.html Accessed 22 November 2020

3. Department of Health (2020) Latest updates on COVID-19 (Coronavirus) https://www.gov.ie/en/news/7e0924-latest-updateson-covid-19-coronavirus/\#the-latest-news-as-of-545pm-onmonday-22-june Accessed 15 March 2020

4. Government of Ireland (2020) Ireland's COVID-19 Data Hub https://covid19ireland-geohive.hub.arcgis.com Accessed 22 November 2020

5. Department of the Taoiseach (2020) Statement by An Taoiseach on measures to tackle Covid-19 https://www.gov.ie/en/speech/ 5a280b-statement-by-an-taoiseach-on-measures-to-tackle-covid19-washington/ Accessed 1 April 2020

6. Department of the Taoiseach (2020) Latest guidance on public health measures https://www.gov.ie/en/publication/a7e66d-latestguidance-on-public-health-measures/ Accessed 14 Aril 2020

7. Department of the Taoiseach (2020) Easing the COVID-19 restrictions on 18 May (Phase 1) https://www.gov.ie/en/publication/ ad5dd0-easing-the-covid-19-restrictions-on-may-18-phase-1/ Accessed 15 May 2020

8. Department of the Taoiseach (2020) Taoiseach confirms Ireland ready to move to Phase $2 \mathrm{https} / / \mathrm{www}$.gov.ie/en/press-release/ bb40a-taoiseach-confirms-ireland-ready-to-move-to-phase-2/ Accessed 10 June 2020

9. Ahuja S, Shah P, Mohammed R (2020) Impact of COVID-19 pandemic on acute spine surgery referrals to UK tertiary spinal unit: any lessons to be learnt? British Journal of Neurosurgery:1-5. https://doi.org/10.1080/02688697.2020.1777263

10. Hecht N, Wessels L, Werft FO et al (2020) Need for ensuring care for neuro-emergencies-lessons learned from the COVID-19 pandemic [published online ahead of print, 2020 Jun 8]. Acta Neurochir:1-7

11. Fahy S, Moore J, Kelly M et al (2020) Analysing the variation in volume and nature of trauma presentations during COVID-19 lockdown in Ireland. Bone Joint Open 1-6:261-266
12. Christey G, Amey J, Campbell A et al (2020) Variation in volumes and characteristics of trauma patients admitted to a level one trauma centre during national level 4 lockdown for COVID-19 in New Zealand. N Z Med J 133(1513):8188

13. Hernigou J, Morel X, Callewier A et al (2020) Staying home during "COVID-19" decreased fractures, but trauma did not quarantine in one hundred and twelve adults and twenty eight children and the "tsunami of recommendations" could not lockdown twelve elective operations. Int Orthop 44(8):1473-1480. https://doi.org/10.1007/ s00264-020-04619-5

14. Park C, Sugand K, Nathwani D et al (2020) Impact of the COVID19 pandemic on orthopedic trauma workload in a London level 1 trauma center: the "golden month" [published online ahead of print, 2020 Jun 23]. Acta Orthop:1-6. https://doi.org/10.1080/17453674. 2020.1783621

15. Nuñez JH, Sallent A, Lakhani K et al (2020) Impact of the COVID19 pandemic on an emergency traumatology service: experience at a tertiary trauma centre in Spain. Injury 51(7):1414-1418

16. Census. Central Statistics Office (2019) StatBank Census Populations. Central Statistics Office. https://statbank.cso.ie/px/ pxeirestat $/$ Statire/SelectVarVal/Define.asp?Maintable= EY029\&Planguage $=0 . \mathrm{A}$

17. National Office of Clincal Audit (2020) Major Trauma Audit National Report 2018 https://www.noca.ie/documents/majortrauma-audit-national-report-2018 Accessed 20 March 2020

18. Schirmer CM, Ringer AJ, Arthur AS et al (2020) Delayed presentation of acute ischemic strokes during the COVID-19 crisis. J Neurointerv Surg 12(7):639-642. https://doi.org/10.1136/ neurintsurg-2020-016299

19. Zhao J, Li H, Kung D et al (2020) Impact of the COVID-19 epidemic on stroke care and potential solutions. Stroke 51(7):19962001. https://doi.org/10.1161/STROKEAHA.120.030225

20. Moroni F, Gramegna M, Ajello S et al (2020) Collateral damage: medical care avoidance behavior among patients with myocardial infarction during the COVID-19 pandemic. JACC Case Rep 2(10): 1620-1624. https://doi.org/10.1016/j.jaccas.2020.04.010

21. Reinstadler SJ, Reindl M, Lechner I et al (2020) Effect of the COVID-19 pandemic on treatment delays in patients with STsegment elevation myocardial infarction. J Clin Med 9(7):2183. https://doi.org/10.3390/jcm9072183

22. Tartara F, Cofano F, Zenga F et al (2020) Are we forgetting nonCOVID-19-related diseases during lockdown? Acta Neurochir 162(7): 1501

23. Irish Medical Organisation (2020) IMO warns that patients may be ignoring serious ailments as a result of \#Covid19 https://www.imo. ie/news-media/news-press-releases/2020/imo-warns-that-patients$\mathrm{m} /$ index.xml Accessed May 182020

24. Evelyn Ring in Irish Examiner (2020) Patients admitted to hospital after delay in seeking GP help https://www.irishexaminer.com/ breakingnews/ireland/patients-admitted-to-hospital-after-delay-inseeking-gp-help-991078.html Accessed April 152020

25. Sugrue CM, Sullivan P (2020) The effect of the ongoing COVID19 nationwide lockdown on plastic surgery trauma caseload? J Plast Reconstr Aesthet Surg 73(7):1357-1404. https://doi.org/10.1016/j. bjps.2020.05.031

26. Valand P, Lloyd N, Robson M et al (2020) Trauma transformed: a positive review of change during the COVID-19 pandemic. Journal of plastic, reconstructive \& aesthetic surgery : JPRAS S17486815(20):30211-30214. Advance online publication. https://doi. org/10.1016/j.bjps.2020.05.037

27. Motterle G, Morlacco A, Iafrate M et al (2020) The impact of COVID-19 pandemic on urological emergencies: a single-center experience. [published online ahead of print, 2020 May 23]. World J Urol:1-5. https://doi.org/10.1007/s00345-020-03264-2

28. Amoo M, O'Halloran PJ, Leo AM et al (2018) Outcomes of emergency neurosurgical intervention in neuro-critical care patients with 
traumatic brain injury at Cork University Hospital. Br J Neurosurg 32(6):585-589. https://doi.org/10.1080/02688697.2018.1522416

29. Huang ZG, Feng YH, Li YH, Lv CS (2017) Systematic review and meta-analysis: Tai Chi for preventing falls in older adults. BMJ Open 7(2):e013661. https://doi.org/10.1136/bmjopen-2016013661

30. Gillespie LD, Robertson MC, Gillespie WJ et al (2012) Interventions for preventing falls in older people living in the community. Cochrane Database Syst Rev 9:CD007146.pmid: 22972103

31. Mitchell P (2020) What could coronavirus teach us? Br J Neurosurg 34(2):117-118. https://doi.org/10.1080/02688697.2020.1756417

32. Sinead Hussey on RTE (2020) Car detected travelling at $202 \mathrm{~km} / \mathrm{h}$ on Dublin's M50 https://www.rte.ie/news/ireland/2020/0522/ 1139928-speeding-roads/ Accessed 12 June 2020

33. Parkinson D (2019) Investigating the increase in domestic violence post disaster: an Australian case study. J Interpers Violence 34(11): 2333-2362. https://doi.org/10.1177/0886260517696876

34. Brooks SK, Webster RK, Smith L et al (2020) The psychological impact of quarantine and how to reduce it: rapid review of the evidence. Lancet 395(10227):912-920. https://doi.org/10.1016/ S0140-6736(20)30460-8

35. An Garda Siochana (2020) Operation Faoiseamh - domestic abuse 9th June 2020 https://www.garda.ie/en/about-us/our-departments/ office-of-corporate-communications/press-releases/2020/june/ operation faoiseamh - domestic abuse 9th june 2020.html Accessed 20 June 2020

36. Women's Aid (2020) Media release: rise in reports of domestic violence in 2019 and during covid-19, says women's aid https:// www.womensaid.ie/about/newsevents/news/2020/08/20/mediarelease-rise-in-reports-of-domestic-violence/ Accessed 23 August 2020

37. Kitty Holland in the Irish Times (2020) Gardaí called to over 27, 000 domestic violence incidents during pandemic https://www. irishtimes.com/news/social-affairs/garda\%C3\%AD-called-to-over27-000-domestic-violence-incidents-during-pandemic-1.4335053 Accessed 23 August 2020

38. Henry McDonald in the Guardian (2020) Domestic abuse surged in lockdown, Panorama investigation finds https://www.theguardian. com/society/2020/aug/17/domestic-abuse-surged-in-lockdownpanorama-investigation-finds-coronavirus Accessed 18 August 2020

Publisher's note Springer Nature remains neutral with regard to jurisdictional claims in published maps and institutional affiliations. 